\title{
Humanistic Elements in the Educational Practice at a United States Sub-Baccalaureate Technical College
}

\author{
Peng Chen ${ }^{1}$ and Carsten Schmidtke*2 \\ ${ }^{1}$ School of Education Science, Jiangsu Normal University, 101 Shanghai Road, Tongshan New \\ District, Xuzhou, 221116, PR China \\ ${ }^{2}$ Human Resource and Workforce Development, College of Education and Health Professions, \\ University of Arkansas, 751 Maple Street, 133B GRAD, Fayetteville, AR 72701, USA
}

Received: 30.08.2016; Accepted: 12.04.2017; Published: 31.08.2017

\begin{abstract}
Humanism has never been able to establish a firm place in technical education, which remains predominantly pragmatist in response to industry needs, certification requirements and educational standardisation. However, after a period of decline, humanism has made somewhat of a comeback as part of the movement toward studentcentred education. Research conducted at a technical college showed that although humanistic elements are largely absent from educational practice in post-secondary technical education, they are not detrimental to the achievement of stated educational objectives. This research indicated that including humanistic elements in educational practice will enable instructors to be more effective in helping students to develop skills in relation to team work, problem-solving, systems improvement, lifelong learning and other areas that are becoming increasingly necessary for success in the workplace. The specific recommendations from this research include a constructivist approach with a focus on contextual teaching and learning using situated cognition, cognitive apprenticeships, anchored instruction and authentic assessment. At the same time, some suggestions for improving professional development for teachers by using a Gestalt approach along with self-study in the context of learning communities have been discussed.
\end{abstract}

Keywords: VET, Vocational Education and Training, Technical Education, Vocational Education, Humanism, Humanistic Methods, Educational Practice

\footnotetext{
${ }^{*}$ Corresponding author: cswded@uark.edu
}

ISSN: $2197-8646$

http://www.ijrvet.net 


\section{Introduction}

Although humanistic elements have been present in education since antiquity, educational humanism came into its own only after World War II. Its early proponents deplored the fact that existentialist thinking in response to the horrors of war had led to a distrust in traditional values, including those that support and encourage learning. Behaviorist teaching was seen by many as unencumbered by outmoded values, but humanists were unhappy with behaviorism's focus on skills training rather than fulfilling human potential and experiencing emotional growth (DeCavalho, 1991).

The breakthrough for educational humanism in the United States came in the 1960s and 1970s. The Civil Rights and Counterculture movements of the 1960s encouraged people to question social values and institutions, so educators began to take a hard look at schools in the inner cities, which tended to enroll large numbers of minority and immigrant students and were often located in high-crime and economically depressed neighborhoods. Scholars attributed the pervasive feeling of hopelessness in these schools to fractured communities, families, and cultures; onerous bureaucracies; and a plethora of social ills like violence, crime, intolerance, poverty, teen pregnancy and suicide, and gang activity. Repairing the social and community structures that could prevent such ills was identified as the best approach, yet Civil Rights legislation did not provide adequate funding. Meanwhile, school buildings were falling into disrepair and teachers remained underpaid, a common problem in the United States where school funding tends to be tied to local property tax revenue. Humanistic education was not seen as a panacea but as a way to balance the various needs and re-ignite in teachers and students a new passion for education (Rogers \& Freiberg, 1994).

When it seemed in the late 1970 and early 1980s that progressive and humanistic ideas might finally be able to gain a foothold in vocational education practice and educators began to pay attention to the lives of workers and their needs like decent work and professional dignity (Kincheloe, 1995), The National Commission on Excellence in Education (1983) published a report titled A Nation at Risk, which set off the academic standards movement that has come to dominate United States education reform. Instead of moving toward more open, individualized, and student-driven practices, vocational education instead moved further toward credentialing, that is, establishing worker qualifications and competencies. Humanistic ideas such as personal development and autonomy were seen as antithetical to effective certification test preparation and the need to conform to market demands (Veugelers, 2011b).

Within the past twenty-five years, however, some authors have once again recognized the value of humanistic ideas for today's educational challenges, called for humanistic education to be "retrieved, reevaluated" (Nemiroff, 1992, p. 5), and promoted a renewed emphasis on personal development, meaningful learning, and social justice (Veugelers, $2011 b$ ) in an effort to improve student learning through the inclusion of issues outside of school and work (Westheimer, 2011). Considering this context, the purpose of this study was to investigate to what degree humanism might still be present in United States post-secondary technical education practice and which benefits instructors perceive in the use of humanistic methods. 


\section{Research Questions}

1. According to instructors' perceptions of their teaching, which humanistic elements are present in the instruction at one United States post-secondary technical college?

2. How do instructors at one United States post-secondary technical college feel about the inclusion and usefulness of humanistic elements in post-secondary technical instruction?

\section{Literature Review}

\subsection{Humanistic Values and Principles}

Humanism focuses on the dignity, autonomy, freedom, integrity, well-being, equity, and potential of learners. Humans enjoy making their own decisions about their lives, and educators must trust that learners' educational choices are indeed well-reasoned (Aloni, 2011; Brockett, 1998; Hitt, 1973; Nakata, 1972; Veugelers, 2011a; Willers, 1975). The ultimate goal of humanistic education is to develop self-actualized individuals (Nemiroff, 1992; Willers, 1975). If learners have control over their own learning, any personal development and increased sense of social justice can help others grow and have beneficial effects on society as a whole (Aloni, 2011; De Groot, 2011; Greenleaf \& Griffin, 1971; Hitt, 1973; Simpson, 1976; Westheimer, 2011).

Weinberg and Reidford (1972) suggested four components of successful learning: a free environment, relating learning to one's own experiences, cooperation, and learning from the inside out. First, students need to have the freedom to delve into any topic they wish for learning to take place (Willers, 1975). Second, students are most motivated when what they learn helps them make sense of their lives and their surroundings. Third, students learn best under a constructive relationship with their instructors where feedback is seen as assistance to promote learning and growth rather than criticism. Finally, the more content is related to learners' self-concept, the more meaningful learning becomes, and the less likely it is to be rejected (Aloni, 2011; Patterson, 1973; Veugelers, 2011b).

To guide students along the path to self-actualization, the instructor's role is to help students grow emotionally and intellectually, to become independent and self-directed learners (Aloni, 2011; Hitt, 1973; Patterson, 1973; Zahorik \& Brubaker, 1972). Learning objectives emphasize not only cognitive but also affective and psychomotor competencies. Instruction takes places through personal experiences in the form of projects, peer teaching, service learning, and the like. Instructors make sure that students have the resources to reach their goals but become involved only in case of student questions or risk of harm (Rogers \& Freiberg, 1994; Veugelers, 2011b). This facilitator role is an integral part of humanistic instruction. Instructors encourage students to explore their interests, develop their talents, and become aware of social welfare issues (Aloni, 2011), and instructor confidence in students' capacity to develop is the starting point for students to take charge of their own learning (Rogers \& Freiberg, 1994; Nemiroff, 1992; Zahorik \& Brubaker, 1972). All these requirements combine to help instructors 
develop the one skill that makes them expert facilitators: personal attention through reflective listening that develops respect for other people's feelings and thoughts and allows students to focus their energy entirely on their learning (Aloni, 2011; Kraft, 1975; Veugelers, 2011b).

Successful instruction is built on a series of conditions defined by Patterson (1973) and guided by sixteen principles listed by Shapiro (1986). These in turn are part of four different levels of involvement: natural learning, co-planning, pulling out the props, and self-direction (Kraft, 1975). Natural learning encourages students to think creatively and express their ideas, form hypotheses, choose methods of finding information to test these hypotheses, and construct knowledge from their findings (Aloni, 2011; Greenleaf \& Griffin, 1971; Patterson, 1973; Veugelers, 2011b). Co-planning helps students think about why they want or have to learn something. Students usually choose a problem that is related to their lives, understand the problem fully, conduct an inquiry, and come up with alternative solutions. Evaluation then looks at outcomes and suggests adjustments and changes for the future (Greenleaf \& Griffin, 1971; Patterson, 1973). In the third level, pulling out the props, a wholesale elimination of teaching aids, textbooks, tests, syllabi, curricula, and grades is envisioned because their true purpose is to force knowledge upon students rather than allow them to seek it and grow on their own terms. The instructor's role is to find out how students learn best and to solve the problem of those reluctant to learn (Greenleaf \& Griffin, 1971).

\subsection{Failures and Criticism}

After being one of the early proponents of a humanistic approach to education, Patterson (1987) conceded that all the benefits humanism was supposed to have brought had not come to pass, and he concluded that humanism was no longer a valued part of the American educational landscape. Several reasons for such an assessment have been proposed:

1. Confounding educational humanism with secular humanism compelled some parents to oppose humanism on the grounds that it was hostile to their religion and led to a collapse of morals (Patterson, 1987).

2. Humanistic instructors were never able to state humanistic principles in clear, concise, and jargon-free language. Instead, their persistent vagueness made everyone wonder how exactly the theory would be applied in the classroom (Conklin, 1984; Patterson, 1987; Willers, 1975).

3. The idea of learners' being responsible for their own learning seemed like something that many students would not be able to do responsibly. If that was so, some asked, was learner responsibility not in fact just another type of instructor preference foisted upon their students? Educators' responses to such challenges were often less than satisfactory (Conklin, 1984). 
4. As a result of the standards-based movement's focus on cognitive and academic development, affective methods were seen as hostile to reaching academic goals (Patterson, 1987).

5. The strong individualism and emphasis on the present, some feared, led to selfish behavior, hedonism, and a lack of concern for social issues, accomplishing exactly the opposite of what humanism set out to do (Brockett, 1998).

6. A focus on the individual must mean that each student needs to be treated separately, and this need for individual approaches leads to a fragmentation of a humanistic whole.

Despite such issues, Patterson (1987) asserted that if changing instructor attitudes and behaviors were part of pre-service teacher training, these obstacles might be overcome. In addition, if the name of the movement were changed (he suggested "invitational learning"), there might be less apprehension among stakeholders and a renewed opportunity for humanism to make an impact.

\subsection{Vocational Education in the United States}

After the beginning of the industrial revolution in the United States in the early nineteenth century, vocational education (now called career and technical education or CTE) saw an increase in the number of industrial schools offering short-term programs to train machine operators in skills for mass production work while comprehensive school-based training programs consisted mostly of theory. The manual training movement of the late 1800s, however, emphasized practical skills and introduced the idea that (1) high school students needed exposure to careers that did not require a college degree and (2) disciplines other than academics could and should be taught in the public schools (Gordon, 2014).

The manual training movement also begot what are probably the two seminal discussions in the history of American vocational education, the debates between Booker T. Washington and W.E.B. DuBois in the closing years of the nineteenth century on the one hand and between John Dewey and David Snedden/Charles Prosser in the second decade of the twentieth century on the other. Washington, the founder of Tuskegee Institute in the State of Alabama, an industrial school for African Americans, believed that vocational education needed to be part of public education because it led to economic independence, which in turn led to better social integration and financial security and eventually more civil rights. DuBois, author, scholar, and one of the founders of the National Association for the Advancement of Colored People (NAACP), a major U.S. civil rights organization, was convinced that integration and economic stability were meaningless without civil rights and insisted that the latter be achieved first (Gordon, 2014). This difference of opinion has remained a contentious topic up until the present day.

David Snedden, professor of educational administration at Columbia University in New York, and his student Charles Prosser, who later became executive director of the 
National Society for the Promotion of Industrial Education (NSPIE), emphasized the integration of theory and practice, productive work as part of the training curriculum, and financial incentives for students. Prosser's sixteen theorems stressed preparing students for the workplace, using instructors with a background in industry, designing training to meet the needs of industry, and limiting vocational education to those interested and motivated to do well in it. John Dewey, longtime professor at the University of Chicago and arguably the most influential figure in American educational reform in the first half of the twentieth century, worried that vocational education had too narrow a focus and made workers too dependent on their industry employers. Instead, he advocated for preparing students for life rather than work, teaching transferable skills, and offering vocational education to everyone. Ultimately, Prosser's idea of a dual system with academic education taught in high schools and technical education in trade schools won out and was reflected in the first major vocational education legislation in the United States, the Smith-Hughes Act of 1917 (Gordon, 2014). This division has remained the de facto standard for American vocational education since.

Education in the United States falls under the purview of each state, meaning that there is no "American" career and technical education (CTE) system per se but 50 different state systems. At the secondary level, CTE tends to be subdivided into the following eight categories: agricultural education, business education, family and consumer sciences education, health occupations education, marketing education, technical education (preparation for technical occupations), technology education (technological literacy), and trade and industrial education (preparation for industrial occupations and re-training). In addition, the U.S. Department of Education has identified sixteen career clusters for broad industry areas that include academic and technical knowledge and skills. Students at this level typically spend part of their time at a comprehensive high school and another part at a CTE facility operated by the local school district or at an area CTE center (Scott \& Sarkees-Wircenski, 2008).

At the post-secondary level, vocational programs are customarily offered at CTE centers, community colleges, or technical colleges. The principal purpose of these programs is preparation for employment and ensuring a supply of skilled workers for industry. Students finishing a CTE center program will earn a certificate or diploma whereas students at community or technical colleges usually earn a two-year Associate of Science (A.S.) or a three-year Associate of Applied Science (A.A.S.) degree. These latter students are subject to the same general education requirements that other college students must fulfill (writing, communication, math, science, American history and government, and other requirements that vary from state to state) and may transfer academic credits to another university. Many colleges also offer certificate programs or corporate training and re-training (Cohen \& Brawer, 2008).

The recent challenge for CTE has been to train enough workers for the high-tech information technology jobs that will keep the U.S. competitive globally as developed countries experience the shift toward a knowledge economy (Gordon, 2014). This task requires better integration of technical and academic education, awareness of cultural issues in an increasingly diverse society, and an improvement in the transition from secondary to post-secondary education and on to the workplace. Difficulties lie in the 
tendency of employers, schools, educators, parents, community organizations, etc., to protect their own turf and be extremely cautious about engaging in true cooperation. Another persistent issue has been the resistance of employers to offering on-the-job experiences to students and paying interns for their work, requiring schools to fill the gap. A third problem has been that some public officials think taxpayer money ought not to be spent to benefit private enterprises while industry resists involvement out of fear that it will get no return on its investment (Kincheloe, 1999).

Hickox and Moore (1995) further argued that the growing emphasis in the United States on credentialing has compelled technical instructors to shy away from using humanistic methods, which are seen as the culprit that prevents students from being prepared for work by not focusing on employment-related knowledge. At the same time, rapid technological advances and the need for retraining resulting from the offshoring of well-paying American manufacturing jobs have led to rising job requirements that are often not matched by rising salaries, and workers become reluctant to engage in more training when the payoff is at best doubtful. Humanism can change this situation in two ways: It can help workers see the contribution of their learning to their personal development and the development of their communities, especially in terms of equity for ethnic minorities, and it can attract new groups of potential employees to advanced technical training in occupations where American employers still have trouble filling available openings (Aikenhead, 2004).

In addition, humanism can help learners lose the fear of basic math and science required for today's high technology training. The emphasis on values, the role of technology in social development, and human interaction relative to technology can help those learners who see technology as irrelevant or even as a threat to their own and their communities' cultural values. The benefits of a humanistic technology education are a better understanding of the connections between technology and the issues relevant to learners' lives; an improvement of critical thinking, problem-solving, and decisionmaking skills; and an encouragement for students to become involved in community development (Aikenhead, 2004). Students will be able to reduce doubt in their abilities, fight issues of low motivation, and make the repeated need for skill upgrading seem less onerous (Nemiroff, 1992).

\subsection{Student-Centered Learning}

Some humanistic methods and ideas have been revived in the movement toward studentcentered education and have reappeared in public education: building on students' interests (Falk, 2009), experiential and explorative learning (Edmiston, 2014; Hopkins, 1994; Roberts, 2012), learning through inquiry (Barell, 2003; Lee, Green, Odom, Schechter, \& Slatta, 2004), the teacher as guide (Hopkins, 1994), freedom and personal development (Falk, 2009; Gitlin \& Peck, 2005; Hopkins, 1994), and authentic assessment (Edmiston, 2014; Falk, 2009). Higher education, too, has been encouraged to make a shift in the same direction. Weimer (2002) proposed five areas where learner-centered instruction could prove useful in improving student motivation and learning: the balance of power between teacher and student (e.g., assignment scheduling, attendance policies), a student 
voice in instructional content, instructor roles, responsibility for learning, and evaluation methods.

However, none of these sources actually used the term "humanism." Even if not humanistic in name, a comparison of student-centered learning with the principles of educational humanism nonetheless shows much overlap and indicates that humanistic ideals may not have been prominent in education for some time but have definitely not been forgotten and are once again seen as a possible solution to issues surrounding student achievement and completion rates.

As for vocational pedagogy, De Bruijn and Leeman (2011) described a competencebased "model of powerful learning environments" for vocational education (p. 695) with several features that could be described as humanistic: reflection, problem-solving activities, the instructor as guide, meaningful and flexible content, frequent low-stakes assessments, and self-regulated learning. However, they had to admit that their research showed only weak implementation of the various aspects of the model, especially reflection, self-regulation, and real-world tasks in real-world environments. The reasons they gave was teacher unease about trying new approaches and a lack of training in teaching methods, leading teachers to rely on familiar traditional methods. Change would first have to begin with organizational development toward a climate where innovation and experimentation are encouraged. Cedefop (2015) reported that although some European countries had made a commitment to learner-centered education, policy support was often weak. Implementation was inconsistent and varied greatly depending on the particular field of study, the size of the participating companies, school administrations, student diversity, and student-teacher ratios.

\section{Conceptual Framework}

The conceptual framework for this study is humanistic adult education as described by Elias and Merriam (2005). It was chosen because it not only corresponds with the major tenets of educational humanism as described in the literature review but also argues that humanistic teaching is appropriate for adults and older adolescents at whom vocational education tends to be directed. Elias and Merriam characterized humanism as being about individual dignity, autonomy, freedom, and integrity. The focus is on whole-person development, especially individual potential and creativity, and does not rely on extrinsic rewards. Typical humanistic practices are experiential learning, selfevaluation, self-determination of learning goals, and reflections on one's own learning with an emphasis on personal growth.

The role of learners is to initiate and evaluate their own learning and progress, participate actively in learning experiences, and engage in reflective thought with the goal of self-actualization (Stephens, 2015). Teachers on their part act as guides and facilitators who encourage their students rather than criticize and judge them. Teachers must make sure that student self-expression and creativity are at the forefront of learning and that learning experiences are always meaningful (Elias \& Merriam, 2005). 


\section{Methods}

The purpose of this study to explore instructor perceptions and attitudes toward humanism and teaching in general led to these research questions: (1) According to instructors' perceptions of their teaching, which humanistic elements are present in the instruction at one United States post-secondary technical college? (2) How do instructors at one United States post-secondary technical college feel about the inclusion and usefulness of humanistic elements in post-secondary technical instruction? To find answers to these questions, the researchers wanted to elicit participants' feelings about and experiences with humanistic instruction, an approach that favors a pragmatic qualitative design. Qualitative interviewing was selected as the primary method to collect data because it is the research interview that puts participants' views front and center in the attempt to uncover knowledge (Kvale \& Brinkmann, 2009; Rubin \& Rubin, 1995). Observation and document collection were added to enable the researchers to discover if and how humanistic approaches were reflected in curricula, course syllabi, and assignments and humanistic methods were implemented in the classroom (Morse \& Richards, 2002).

\subsection{Participants and Setting}

The study's participants were instructors at Great Plains Technical College (GPTC), a technical college in the United States with a focus on post-secondary technical education. The college offers mainly Associate of Applied Science (A.A.S.) degrees in different technical areas such as automotive, construction, heavy equipment, air conditioning, engineering, information, and health and environmental technologies; Associate of Science (A.S.) and Bachelor of Technology (B.T.) degrees in information and engineering technologies; and corporate training through its workforce and economic development unit. GPTC is known for its hands-on technical education and unique partnerships with industry. Participants all held at least a bachelor's degree in their respective fields. Those who had also earned a master's degree had done so in a variety of fields such as engineering, information technology, business, or education but had had little to no exposure to educational philosophy. As a result of the college's focus on workforce education, most participants had had prior industry experience before joining the faculty at GPTC.

Three divisions, Information Technologies (IT), Engineering Technologies (ET), and Arts \& Sciences (A\&S), were used to collect data as these were divisions where the researchers were granted access to faculty members, classrooms, and documents. These divisions offer specializations in civil engineering, electrical/electronics, engineering graphics, instrumentation technology, and manufacturing (ET) and network infrastructure, software development, cybersecurity, and IT enterprise management (IT). All specializations are rather prescriptive, leaving no room for elective coursework. Class sizes depend on shop or laboratory restrictions. Classes with as few as 4 and as many as 16 students were observed. The average campuswide class size is 14. The A\&S division was added because it provides all general education courses for IT and ET students and allowed a comparison to see if general education coursework and instructors might be more amenable to humanistic methods. 
Complete target population sampling (Patton, 2002) was attempted, but not all potential participants agreed to participate in the study. Fourteen instructors ultimately consented to be interviewed: three from IT, six from ET, and five from A\&S. There were nine males and five females among the participants.

Table 1: Participant Names and Specialties

\begin{tabular}{llll}
\hline Name & Gender & Dept. & \multicolumn{1}{c}{ Program Areas } \\
Raymond & Male & IT & Information Technologies \\
Frank & Male & IT & Information Assurance \\
Gavin & Male & IT & Information Assurance \\
Liz & Female & ET & Nanotechnology \\
Mike & Male & ET & Electrical/Electronics Technologies \\
Dora & Female & ET & Civil Engineering \\
Christian & Male & ET & Engineering Graphics \\
Hank & Male & ET & Engineering Graphics \\
Max & Male & ET & Manufacturing Technology \\
Linda & Female & A\&S & Communications \\
Michelle & Female & A\&S & Communications \\
Robert & Male & A\&S & Social Sciences \\
Luann & Female & A\&S & Humanities \\
Adam & Male & A\&S & Math and Science \\
\hline
\end{tabular}

\subsection{Data Collection}

Semi-structured interviews of 30-45 minutes were conducted with all participants. The interview protocol included fourteen major questions about professional background and self-perception as a teacher, courses taught, course competencies and content, relationships with students, instructional methods, and distinguishing characteristics of technical college instructors. Observations were conducted as selective observation with passive participation (Savin-Baden \& Major, 2013) based on the protocol developed by Cas- 
sady, Neumeister, Adams, Dixon, and Pierce (2004). During observations, instructional activities (delivery of information, interaction between instructor and students and between students, student and instructor activities), the person making learning decisions, cognitive activities by levels of complexity, and classroom management as well as the classroom environment were observed and recorded. Documents came from the college, the divisions, and the instructors themselves: strategic plan and assessment documents, degree plans and curricula for different degrees, class schedules, departmental assessment reports, syllabi, and various teaching materials.

\subsection{Data Analysis}

Data analysis was conducted as "content analysis" (Rossman \& Rallis, 2003, p. 198). Coding included steps of open coding (Flick, 2002; Patton, 2002), focused coding (Patton, 2002; Rossman \& Rallis, 2003), and selective coding (Flick, 2002). In the first coding step, open coding (Flick, 2002; Patton, 2002), the researchers immersed themselves in the data by reading the transcripts line by line several times and jotting down first codes representing interesting and emerging ideas, unexpected information, and possible items that might indicate patterns and themes. A second round of open coding was conducted to see if any of the codes could be grouped together.

In the next step, interview transcripts with codes and categories clearly applied were refined and expanded in focused coding (Patton, 2002; Rossman \& Rallis, 2003). The purpose of this step is to choose the categories that are most likely to provide answers to the research question, assign the different data segments to these categories, and decide which codes should function as major categories and which ones as subcategories (Flick, 2002). The final step, selective coding (Flick, 2002), is used to develop core categories or themes from the categories at hand. The researchers integrated the categories around such central ideas, once again working across categories to look for any connections that had gone unnoticed, and ended up with three themes around which the categories could be grouped.

\subsection{Trustworthiness and Rigor}

Lincoln and Guba (1985) suggested that the criteria of credibility, transferability, and dependability be used to establish trustworthiness and rigor of a qualitative study. Credibility was assured through detailed field notes with particular emphasis on context and participant comments, the use of emic codes whenever possible, a search for alternative themes and categories through data reorganization, and a data check across categories. To allow a level of transferability, the researchers described the complete process of data gathering, analysis, and interpretation as well as the setting in detail. The more pertinent detail has been provided, the easier it is to identify another context as sufficiently similar and check if findings may apply. Dependability was established through a careful check of data sources and an audit trail, that is, a step-by-step documentation and accounting of each part of the research process (Meriam, 2009). 


\subsection{Limitations}

The first limitation was geographical. This research was conducted at only one subbaccalaureate technical institution in one region of the United States. Second, the study was limited to participants from three of the nine academic divisions at GPTC because those were the ones where access was granted. Third, not all instructors agreed to be interviewed, which resulted in participation rates of 43 percent for Information Technologies, 40 percent for Engineering Technologies, and 17 percent for Arts \& Sciences.

\section{Findings}

Findings revealed that the major characteristics of humanism according to Elias and Merriam (2005) such as a focus on personal growth and development, self-evaluation of one's learning, reflective thought leading to self-actualization, and teachers providing autonomy, freedom, and meaningful learning were not mentioned in interviews or documents nor were observed in the classroom. Therefore, Research Question 1 can be answered that although instructors used occasional methods and exhibited behaviors that can be seen as falling within a humanistic spectrum, they did not appear to be the result of an underlying systematic humanistic philosophy. Therefore, no unmistakably humanistic elements were present in the instruction at GPTC. As for Research Question 2 , instructors seemed unaware of humanism and other educational philosophies, evidenced by the fact that no references to humanism or any other philosophy were made. Therefore, they expressed no feelings toward the inclusion and usefulness of humanistic elements in their teaching. The three major emic themes concerning teaching and learning at GPTC that emerged from the data instead were working in teams, helping students succeed, and looking for a good job.

\subsection{Working in Teams}

Teamwork featured in the curriculum as both the Information Technologies (IT) and the Engineering Technologies (ET) divisions allowed their students to take a course in small group communication instead of the traditional public speaking course required by many American universities. Mike stated the reason as follows: "[W]hen they join the workforce, they will most likely not be working by themselves. The student is therefore taught to work in a team environment."

The potential benefits of teamwork, especially helping classmates achieve better understanding and developing critical thinking skills, seemed to be clearly understood and described by all IT and ET participants. Liz's statement is one example: "Students working together is highly beneficial because everyone knows how it is done and how they argue to learn and approach the problem. From that, they learn critical thinking skills." Although critical thinking, problem solving, stating and supporting opinions, and learning the steps of each task through cooperation were brought up as work-related skills learned through teamwork, they went unrecognized as elements of humanistic teaching. Work teams were merely seen as a way to disseminate new information and as a resource 
for employees who had questions to effect higher productivity and efficiency. Gavin explained it like this: "When I was in industry, I would go to the guy in the next office and say, "Hi, guy, come here and help me figure this out to understand it."'

In practice, however, participants in general simply allowed their students to complete their assignments in teams if they wished to consult with classmates as stated by Raymond: "The students can help each other because somebody might understand more and someone else not understand something." Students could work in larger or smaller teams based on class size to help one another, but they were not required to do so. Team projects were not used until students were in more advanced classes: According to Hank, "The only time they work in a team is when they are given the big project."

Raymond advocated project learning as part of teamwork and discussed planned team projects: "It is good to incorporate interesting projects in classes. Then the students will get more engaged and want to come to class and want to do stuff." However, he also made it clear that these projects were all planned by him. Two concerns about teamwork were also raised. Dora stated that she kept team size to two or three students because in larger teams, there were always team members who did little or no work, and Christian feared that when working in teams, students might end up doing each other's work: "At times in some classes, I encourage the students to work together, but not do each other's work, just help each other."

Considering these responses, it came as no great surprise that the courses in which teamwork played a more prominent role were all located in the Arts \& Sciences division. During the observation of a physics class, Adam divided the students into five groups and let each group carry out an experiment while offering guidance. Each student had his or her own task to conduct and to verify hypotheses. He said, "Only if students experience the whole course of a task can they grasp a certain knowledge point and then apply it." The syllabus for the small group communications course asked students to complete multiple projects such as designing and constructing a flag representing their team or creating a PowerPoint presentation on a specific topic.

Despite recognizing the importance of teamwork, participants were much more emphatic when it came to the benefits of individual learning. Gavin actually preferred his students to work individually. He stated the benefits of individual work like this: "When students apply for jobs and go on interviews, they are on their own and not on a team." Mike agreed that in foundational classes, individual learning was indicated to verify that all students had mastered foundational skills: "The benefits of working independently come in the basic classes, which are the foundation. Those things need to be learned on their own." In fact, Liz mentioned that independent learning helped students believe in their ability: "For the introductory classes, the students need to work independently so they can get confidence and the skills they need." Gavin agreed that students learn more quickly individually: "I prefer to let the students work independently most of the time because I think that the student can learn quietly a little quicker on their own."

The findings show that although participants understood the benefits of teamwork, they still preferred that students complete most of their work individually. Teamwork was tolerated when students could learn from one another or when struggling students could benefit from collaborating with their classmates, but it was rarely encouraged or 
even required, suggesting that teamwork benefits were seen strictly in terms of skills development rather than principles like student growth and independence mentioned by Elias and Merriam (2005).

\subsection{Helping Students Succeed}

Instructor-centered teaching was the default approach to classroom interaction mentioned by the majority of participants and expressed clearly by Hank: "I try to teach them concepts they need to learn." Students were not encouraged to explore their own topics; Frank, for example, made the choice for them: "I try to find something interesting and find ways to put it into the course."

The purpose of helping students was to allow them to pass the class, not to enhance their personal development. Max said, "I offer tutoring to them one or two students at a time outside of class time until they become competent in the course content." Help tended to be conservative in the form of open lab hours, tutoring during office hours, or peer tutoring in class and involved mostly giving students a modicum (but not more) of freedom to catch up or not fall behind as in Frank's case: "If I see some students have problems or difficulties, I will provide extra time in either the lab or in theory class." Dora emphasized that every student deserved the opportunity to be successful: "Instructors must investigate and know about the background and situation of every student so as to provide appropriate and special help for them." However, all students were judged on their ability to meet industry standards and were expected to be proactive about their success. Hank explained, "It can be hard for some students to succeed since industry standards drive outcomes. Students must be a good match for the program and must ask questions when they have problems."

The approach to teaching fast learners was a little less restricted. Frank illustrated how he provided classes where students met all competencies early with additional materials to deepen and extend their knowledge and skills: "If they finish everything the first couple of weeks, I give more complex projects to anybody else in the class the rest of the semester and have them work on it." However, such projects were "given" by the instructor rather than initiated by students. It therefore came as a surprise that in this climate of outcome focus and instructor centeredness, Frank actually engaged in a truly humanistic method. The beneficiaries were individual advanced students who had finished their tasks early and needed additional work to occupy themselves. He allowed such students to research on their own a topic that they were interested in: "If I find some students who have interesting things, I can help them and take time out to help more. Try to research something and help them with whatever they are interested in." Unfortunately, instead of being allowed to set their own goals, students again would be expected to reach the goals set for them by him: "I set high goals for the highly motivated students and help push them toward those goals." Teacher centeredness prevailed once more, and independent student research remained ancillary, was not a core feature of student learning, and was not understood as being humanistic.

Help for students was afforded only in terms of allowing them to meet industry standards successfully, not to grow as individuals and experience true independent learning. 
Advanced students who were ahead of their classmates were granted a little more freedom although their learning was still controlled by what the instructor deemed appropriate and useful. Once again, Elias and Merriam's (2005) principles rated no mention.

\subsection{Looking for a Good Job}

Course curricula and instructional methods were linked to future workplace success for students, not to any principles stated in the framework for this study. Because the majority of GPTC students plan to enter the workforce upon graduation rather than transfer to another university, course content and teaching methods were approached in a utilitarian fashion with a focus on teaching required job skills. Industry input into the curriculum was sought and accepted, and personal growth was not at all considered in instructional design and development. Hank explained the relationship between coursework and the workplace as follows: "If they know enough information, they can get better at their job." He saw his ultimate role in preparing students for the workplace: "The students come here just to learn and be trained for the workforce." The reason given for this stance according to Liz was student desires: "Technical education students are looking for a good job when they get out of college."

To accomplish the goal of preparing students for the workforce, technical programs at GPTC rely heavily on industry advisory committees comprised of supervisors and executives from area businesses and industry. Frank declared, "Technical content is determined by the advisors in industry." The curriculum revision process begins with program requests for new content, Liz remarked: "And [they] ask the industry to tell them what technical skills are needed and keep updating and changing." The advisory committees meet twice a year, Raymond revealed, and inform instructors on what needs to be taught: "They come here twice a year and tell the teachers what they need in industry according to which the teachers modify and incorporate new stuff into the courses." One IT syllabus included the following statement to that effect: "Coursework is based on industry standards and the level of the class is specifically designed for industry-level competencies." Instructors subsequently incorporate curriculum content updates into their courses. Although they are free in matters of instructional design, recommended content was accepted by Max as a matter of fact: "Whatever is going on in industry at the time is what I am trying to give to my classes. Because that's the job."

\section{Discussion and Recommendations}

The answers to the two research questions, that is, none of the principles of humanism according to Elias and Merriam (2005) were mentioned or observed and participants seemed unaware of humanism and other educational philosophies, leave the issues of interpreting observations and responses that could be considered part of the humanistic spectrum, examining reasons for the absence of humanistic methods, and identifying opportunities for and benefits of re-introducing humanism into vocational education. 
Loftis (1980) described vocational instructors as "characteristically pragmatic in philosophy and practice" (p. 25), and Miller and Gregson (1999) identified pragmatism as a philosophy that can guide vocational education through the economic and social challenges of the twenty-first century. To that end, they recommended a type of pragmatism they called "reconstructionist":

The overarching purposes of vocational education should be to help facilitate the growth of learners who are competent as: problem solvers, collaborators, makers of meaning, lifelong learners, worker-citizens adaptable to change and active as change agents, and practitioners of democratic processes. (p. 32)

Pragmatist methods according to Elias and Merriam (2005) include the instructor as facilitator who organizes the learning environment and designs experiments through which students can experience self-directed learning. Problem-based inquiry, contextualized learning, project work, experimental learning, and collaborative assignments are all part of pragmatist methods. These two descriptions of pragmatism led the researchers to infer the following:

1. The overlap of pragmatist and humanistic methods when comparing Elias and Merriam's (2005) characteristics of both pragmatism and humanism as well as Loftis' (1980) statement about the pragmatic orientation of vocational instructors suggests that since participants appeared to have no familiarity with educational philosophies and never used the terms humanism or humanistic, it is reasonable to assume that they were operating from a traditional pragmatist framework and that possible humanistic methods and behaviors mentioned or observed belonged to the areas of overlap with humanism but were actually pragmatist.

2. Miller and Gregson's (1999) description of a reconstructionist pragmatism that encourages students to have a voice in the decisions about their learning, look at work in terms of personal growth rather than simply technical skills, participate actively in educational activities, strive to become active citizens, and use their knowledge, skills, and values for the betterment of society parallels humanistic values and indicates that there may indeed be a role for humanism in vocational education if not in name, then possibly in practice.

\subsection{The Absence of Humanistic Elements}

As mentioned in the Findings section, humanistic values and principles like individual dignity, autonomy and freedom, whole person development, self-evaluation, selfdetermination, and reflection were neither mentioned nor observed. The reasons for this absence can most likely be found in the ultimate goals of humanistic education: help students reach self-actualization and give them control over their own learning. GPTC is a technical college with significant ties to industry and heavy reliance on industry advisory groups. As affirmed by participants, industry needs drove curriculum content via the advisory groups, and instructors saw themselves as guarantors that graduating 
students possessed the technical skills industry had identified. Industry demands were front and center of everything that happened in the classroom, and the focus was on mastery of a certain skills set in a pre-defined period of time.

For example, participants implemented teamwork, the first theme, because of its utilitarian and pragmatic function of helping prepare students for the workplace and finding a job, the third theme. Personal growth and development as a result of teamwork were not assessed at the division level, were not mentioned in any documents, and were not cited by participants; instead, teamwork skills were closely cued to industry needs. The second theme, helping students succeed in terms of mastering course content also seemed to be less about student growth than about outcomes, work readiness, and the ability to find suitable employment. In that context, the researchers did observe an occasional use of behaviorist methods when instructors expected their students to perform certain tasks to industry standards and specifications (Elias \& Merriam, 2005).

Although students in general education coursework had some choice in, for example, the exact details of an assignment or the topic of a paper, this is a far cry from expressing ideas about a topic and then exploring knowledge to test those ideas. Neither relating matters to students' own experiences nor focusing on students' self-concept was considered. If GPTC instructors allowed their students to take charge of their own learning, it was generally by giving them enough time to learn the material at their own speed.

The approach of the instructor as facilitator who designed activities and then walked around the classroom, observed students, and intervened when there was trouble clearly predominated in instructor behavior. Mike's syllabus, for example, underscored instructor control of classroom learning: "It will be my role to guide you through the process of studying IT, to provide you with an occasion to think and explore computers." A classroom observation of a group assignment revealed that students had been given the purpose and the expected outcome of the task beforehand. The instructor was thus sole initiator and planner of the activity and its objectives, making it pragmatist rather than humanistic. If any instructor behavior that could belong in the humanistic camp was brought up, it appeared to be without the participants' appearing aware of its humanistic orientation. For example, when asked about the most important quality of technical education instructors and the recommendations they would have for others, participants mostly answered that they should be patient, encouraging, friendly, kind, enthusiastic, and fair, not realizing that these were in fact humanistic principles.

What is the verdict on projects and teamwork, peer teaching, instructor guidance, experimental learning, helping students, and setting individual expectations when a student struggled and was allowed some leeway in keeping up with the class, all of which were mentioned by participants or observed and could be classified as humanistic? Given that Elias and Merriam (2005) placed these methods and behaviors in the pragmatist camp and that participants never spoke about humanism, it is reasonable to assume that they were used as expressions of the overall pragmatist orientation to prepare students to find good jobs rather than as opportunities to inject humanistic ideas into the instructional environment. 


\section{Opportunities for Humanistic Elements in Vocational Education}

Although Scott (1980) conceded research findings that outcomes or achievements are not improved through humanistic instruction, he also proffered the contention that in a more humanistic setting, students generally show more positive attitudes toward learning, spend more time on task, and actually finish learning tasks quicker than otherwise. The findings thus raise the question of where in this era of credentialing and industry collaboration, humanistic values, principles, and methods might still have a place in vocational education. When the entire focus of a class is on helping students reach standards and master skills requested by industry advisors, where is the freedom instructors have to help their students grow and mature rather than simply turn them into skilled workers? Believing that student growth and maturity are not mutually exclusive with teaching specific technical and workplace skills, the researchers have some suggestions for administrators, instructors, and researchers who focus their work on technical education. Some of these recommendations were proposed several decades ago but either not implemented or implemented but not studied, so we know little about their effectiveness. If they can help make contemporary vocational education practice more effective as Miller and Gregson (1999) surmised in their advocacy for a reconstructionist pragmatism, they definitely deserve a second look.

Technical college administrators need not fear that personal growth and development are a distraction for students as they prepare to enter the workforce. In fact, Scott (1980) argued that flexibility in teaching methods has the potential to save money, which should be attractive to those seeking to contain the costs of program administration. Bransford, Brown, and Cocking (2000) emphasized that recent studies have favored a constructivist approach to learning where new knowledge is built on what students already know. They further asserted that to be effective, learning environments had to be learner-, knowledge-, assessment-, and community-centered, that is, focus on the knowledge and skills students already possess, understanding and knowledge transfer, feedback and revision, and the use of the classroom, the school, and the surrounding community respectively. Although Gray and Herr (1998) cautioned that some technical skills, especially those that involved a risk of injury, would likely continue to be taught in a behaviorist fashion, they nonetheless agreed that constructivism had come to play an important role in vocational education as well. Crawford (2001) added that constructivism allowed students to learn by thinking about solving problems, asking questions, exploring possible answers, explaining their decisions, and integrating technical, scientific, and other knowledge. Especially in post-secondary workforce education, attention ought to be paid to students' prior experiences, teamwork, clear expectations, self-direction, learning styles, and cultural differences, all of which fall on the humanistic spectrum. Bransford, Brown, and Cocking (2000) and Fürstenau (2003) supported this argument by contending that traditional pedagogy could develop understanding or skills but not both simultaneously as is needed for modern vocational education. When Spitze (1980) argued for relevant content, adequate timing (e.g., content sequencing, time spent 
on certain topics, etc.) and appropriate materials and methods such as building learning from simple to complex as crucial for successful vocational teaching; instructional variety; experiences of success; independent learning; clear usefulness of learning situations; and student agency in choosing teaching methods, she not only stressed the applicability of humanistic methods to vocational education but also anticipated some of the characteristics of Bransford, Brown, and Cocking's learning environments. Therefore, vocational instructors wanting to heed Spitze's call can consider four methodological approaches: anchored instruction, situated cognition, cognitive apprenticeships, and authentic assessment. All four approaches support Bransford, Brown, and Cocking's concept, complement one another as well as modern vocational education and its pragmatist orientation, and embrace the humanistic ideas and methods mentioned by Elias and Merriam (2005).

A cognitive apprenticeship is the structured acquisition of skills where an expert guides a learner to mastery. Six main steps are usually recognized: (1) modeling (expert performs the skill), (2) coaching (expert observes learner and offers feedback), (3) scaffolding (activities progress from lower to higher skill levels based on learner needs), (4) articulation (learners explain their knowledge and processes), (5) reflection (learners criticize their own performance), and (6) exploration (learners solve problems on their own) (Collins, Brown, \& Newman, 1989; Dennen, 2001; Woolley \& Jarvis, 2007). Fürstenau (2003) implied that cognitive apprenticeships encourage learner-centeredness because the scaffolding process lets individuals control their progress, build on previous learning, and determine the pace at which they are ready to move on to the next level. The knowledge transfer from understanding to application and from simple to complex also supports knowledge-centeredness. Frequent formative assessment takes place at every step of the scaffold as students articulate and reflect on their new skills. Potential humanistic elements are the participatory aspect, the learning from experience, the self-evaluation of one's progress, and the guiding function of the teacher. Finally, cognitive apprenticeships are a good match for vocational education because many instructors have extensive industry experience and possess the expertise to model skills and guide their students incrementally from simple to complex tasks, which is often the approach to vocational skill development.

Anchored instruction grounds learning in real-world applications. It is usually built around an initial problem or situation (the "anchor") whose purpose is to create interest in a topic and guide students toward defining and understanding the problem. The reason for using an anchor is to train students how to identify the most significant issues that need solving (Bransford, Sherwood, Hasselbring, Kinzer, \& Williams, 1990). Using the anchor to build on students' prior experiences and generate understanding makes this method both learner- and knowledge-centered, and the guidance toward solving the initial problem allows for formative evaluation along the way. Among other humanistic principles, anchored instruction fosters individual creativity, active participation, and meaningful learning. An anchor is useful in vocational education in that it helps students deal with situations commonly encountered in the workplace, that is, mechanical or technological problems that must be understood, diagnosed, and solved.

To make sure that the anchor is indeed meaningful, anchored instruction often em- 
ploys situated learning, meaning that the anchor is situated in students' professional or private (social, cultural, linguistic, etc.) environments and helps students learn by showing them how their activities are relevant to their real lives and their unique circumstances (Dennen, 2001; Woolley \& Jarvis, 2007). Situating anchors reinforces learnerand knowledge-centeredness because it considers experience and knowledge transfer and also adds the element of community-centeredness. Even in vocational education, students' social, cultural, and community environments have an important role in learning. According to Fürstenau (2003), if students see how their technical skills can benefit their families and communities, they will find meaning in what they are learning, set their own goals, participate actively, and are more willing to use self-expression, improving motivation and retention in the process.

Although Gray and Herr (1998) claimed that in vocational education, most if not all assessment is authentic because performance of actual work skills is being tested, there is more to authentic assessment than that, namely the integrated assessment of knowledge, skills, and attitudes as well as collecting evidence of mastery at multiple steps along the way (Darling-Hammond \& Snyder, 1998), called formative assessment. Doing this affords teachers the opportunity to provide frequent constructive feedback and help student develop self-confidence and mastery rather than offer a summative critique at the end with no chance to revise performance. According to Bransford, Brown, and Cocking (2000), frequent feedback helps with understanding, allows students to reflect on their thought processes, and also improves the quality of feedback by helping instructors be clearer and more supportive. To measure vocational competencies in particular, Winther and Achtenhagen (2009) argued that knowledge situated in real-world environments be assessed, integrating general academic and specific occupational skills with problemsolving as the ultimate achievement. Winther and Klotz (2013) further recommended that such assessments focus on the process and move from simple to complex and from general to specific tasks, an approach that aligns with Fürstenau's (2003) attitude toward situated learning. Both Winther and Achtenhagen's and Winther and Klotz's arguments for assessment and measurement thus support the notion that cognitive apprenticeships, situated learning, and anchored instruction are appropriate for vocational education pedagogy because all encourage problem-solving in a step-by-step learning process that includes self-assessment, formative evaluation with frequent feedback, and revision of one's performance.

Contextual teaching and learning (CT\&L) has been touted as modern vocational pedagogy's answer to especially the challenges of teaching academic and occupational skills and overcoming the disconnect between school and work and is generally understood to include problem-based learning (PBL), self-regulation, use of multiple contexts, inclusion of students' life environments, team learning, and authentic assessment (Johnson, 2002; Sears \& Hersh, 1998). Despite CT\&L's general pragmatist orientation, its focus on inquiry; experiential learning; a teacher who facilitates; and personal development through the integration of cognitive, affective, and psychomotor skills needed for problem-solving does accommodate the methods discussed here quite well. PBL usually begins with an anchor that is situated in students' experiences, cognitive apprenticeships allow self-regulation, situated cognition makes use of multiple contexts and the inclusion 
of students' life environments, authentic assessment is part of CT\&L in the first place, and all four methods promote formative assessment. In short, using these four methods in the context of CT\&L allows instructors to stay true to their pragmatist roots while extending their teaching to include humanistic principles and goals.

How can humanistic principles, methods, and behaviors for vocational education be learned? Professional development can be offered to faculty members on how to cultivate student growth in their coursework in a way that enhances technical skill development rather than impede it. Although the overwhelmingly pragmatist orientation among technical instructors is acknowledged, there is nothing to stop them from being patient, encouraging, friendly, kind, enthusiastic, and fair to their students, attitudes that do not conflict with technical education and that participants themselves acknowledged as helpful. Humanism also asks faculty members to give students empathetic understanding, high expectations, trust, and reflective listening, none of which are antithetical to technical education (Newcomb, 1980).

It has been said that the problem with many teacher professional development programs has been their generic nature when teachers, especially in vocational and technical fields, would benefit from learning about how to develop methodological skills appropriate for their disciplines. As a result, specific teacher development programs that can train instructors in methods like the ones recommended in this section must be offered (Bransford, Brown, \& Cocking, 2000). One such program could be the in-service teacher professional development program begun at Winthrop College (now Winthrop University) in Rock Hill, South Carolina, in 1972 and originally designed to help vocational instructors move from a predominantly pragmatist approach focusing on skills development to one stressing human development. In this program, vocational instructors and administrators unaware of humanistic principles and methods were introduced to the importance of the affective domain and topics such as relationships and trust, group processes, decision making, and values clarification (Loftis, 1980).

This model could incorporate teacher self-study in the context of teachers' learning communities. Gestalt psychology with its emphasis on cultivation of the whole person, reflection to develop deep insights, relationships with students and colleagues, and meaningful learning, all of which correspond with humanistic principles, has been identified a good basis for such self-study. A gestalt approach includes a learning community of teachers where participants interpret classroom experiences and discuss problems, listen to other viewpoints, share experiences and grow knowledge, and use autobiographical journaling and oral reflections to gain deeper insight into their teaching choices (Bransford, Brown, \& Cocking, 2000; Allender \& Allender, 2008; Frydaki, 2011). Such professional development can create open communication, help instructors develop collaborative relationships to trust and learn from each other, and foster a willingness to try new approaches to teaching and learning. Experienced instructors have to realize the important role of the learning community and give younger instructors professional direction, and younger instructors must ask for suggestions from their experienced colleagues. The model may also be useful to administrators trying to introduce their employees to a more caring approach toward student support (Bransford, Brown, \& Cocking, 2000; Frydaki, 2011; Loftis, 1980). 
Other recommendations can also be implemented. For example, Law (1980) suggested that administrators bring back the position of technical supervisor to offer instructional support. The technical supervisor would not be an administrator but rather a resource person who advocates for instructor needs with the administration, offers workshops and professional development, establishes individual teaching development plans with instructors, helps onboard new instructors with industry backgrounds but little teaching experience, and participates in the choice of instructional materials. Such a person could be ideally suited for identifying and promoting opportunities for humanistic environments, instruction, and instructor behaviors or for facilitating learning communities as part of the Winthrop model.

\subsection{Implications for Researchers}

Researchers can revisit existing humanistic approaches and investigate their applicability to practical problems in contemporary vocational education. First, humanistic management ideas and measures should be studied. Instructors often consider themselves to be passive recipients of administrative actions, which is un-humanistic. What researchers could do instead is to explore more participatory management systems to see if there is room for more humanistic support for students.

Second, cooperative relationships among instructors must be promoted. Therefore, researchers are encouraged to inquire into how cooperative relationships and trust among faculty members may be facilitated in the context of learning communities and how these may be modified to meet the specific needs of vocational instructors. A study that implements and assesses the effectiveness of the components of the Winthrop model may be a good first step here.

Third, a serious look must be taken at the benefits and the costs of humanistic education. Do the monetary savings that are touted by some proponents like Scott (1980) and Spitze (1980) really materialize? If students possibly do not learn better, will they learn faster? Might an investment in additional student support staff members lead to an ROI in terms of higher graduation rates, tuition revenue, and job placement rates? Investigating these questions may be crucial because financial matters are likely to be a major consideration in whether humanistic approaches to education constitute a true improvement to current practices and will be (or should be) adopted on technical college campuses.

\section{Conclusion}

Occasional glimpses of humanistic principles appear at GPTC in teaching methods, the learning environment, and the way in which instructors allow students some freedom and employ teamwork or project learning. Overall, however, the instructor's approach to teaching and learning appears solidly pragmatist and employs humanistic methods only accidentally. If humanistic methods are chosen, instructors tend to be unaware of the fact. In the current climate of credentialing, preparing students for certification tests, and working closely with industry advisory committees, a shift to a truly humanistic 
model is not likely to occur.

None of this means that technical education cannot benefit from the inclusion of humanistic ideas and methods, and using such methods likewise does not mean that necessary pragmatist aims must be abandoned. Miller and Gregson's (1999) recommendation of a reconstructive pragmatism for vocational education points to one way of harnessing the power of humanistic teaching. The argument has even been made that humanistic teaching methods not only improve student motivation but also save time and money. Such claims certainly deserve further investigation on the part of researchers. Where student success is concerned, educators need to use the entire tool chest of approaches at their disposal, not just those conforming to the current educational credo. 


\section{References}

Aikenhead, G.S. (2004). The humanistic and cultural aspect of science and technology education. Paper presented at the $11^{\text {th }}$ International Organization for Science and Technology Education (IOSTE) Symposium, Lublin, Poland.

Allender, J.S., \& Allender, D.S. (2008). The humanistic teacher: First the child, then the curriculum. Boulder, CO: Paradigm Publishers.

Aloni, N. (2011). Humanistic education: From theory to practice. In W. Veugelers (Ed.), Education and humanism: Linking autonomy and humanity (pp. 35-46). Rotterdam, Netherlands: Sense Publishers.

Barell, J. (2003). Developing more curious minds. Alexandria, VA: Association for Supervision and Curriculum Development.

Bransford, J.D., Sherwood, R.D., Hasselbring, T.S., Kinzer, C.K., \& Williams, S.M. (1990). Anchored instruction: Why we need it and how technology can help. In D. Nix and R.J. Spiro (Eds.), Cognition, education, and multimedia: Exploring ideas in high technology (pp. 115-141). Hillsdale, NJ: Erlbaum.

Bransford, J.D., Brown, A.L., \& Cocking, R.R. (Eds.). (2000). How people learn: Brain, mind, experience, and school. Washington, DC: National Academy Press.

Brockett, R.G. (1998). Humanism as an instructional paradigm. Retrieved from http://roghiemstra.com/romira1.html

Cassady, J.C., Neumeister, K.L.S., Adams, C.A., Dixon, F.A., \& Pierce, R.L. (2004). The differentiated classroom observation scale. Roeper Review, 26(3), 139-146. doi: $10.1080 / 02783190409554259$

Cedefop. (2015). Vocational pedagogies and the benefits for learners: Practices and challenges in Europe (Cedefop Research Paper No. 47). Luxembourg, Luxembourg: Publications Office of the European Union.

Cohen, A.M., \& Brawer, F.B. (2008). The American community college (4th ed.). San Francisco, CA: John Wiley \& Sons.

Collins, A., Brown, J.S., \& Newman, S.E. (1989). Cognitive apprenticeship: Teaching the crafts of reading, writing, and mathematics. In L.B. Resnick (Ed.), Knowing, learning, and instruction: Essays in honor of Robert Glaser (pp. 453-494). London, United Kingdom: Routledge.

Conklin, K.R. (1984). What's wrong with humanistic education? Focus on Learning $10(2), 58-68$.

Crawford, M.L. (2001). Teaching contextually: Research, rationale, and techniques for improving student motivation and achievement in mathematics and science. Waco, TX: CORD.

Darling-Hammond, L., \& Snyder, J. (1998). Authentic assessment of teaching in context. In K.R. Howe, S. Sears, R. Berns, J. DeStefano, \& S. Pritz (Eds.), Contextual teaching and learning: Preparing teachers to enhance student success in and beyond school (pp. 253-294). Columbus, OH: ERIC Clearinghouse on Adult, Career, and Vocational Education and Washington, DC: ERIC Clearinghouse on Teaching and Teacher Education.

De Bruijn, E., \& Leeman, Y. (2011). Authentic and self-directed learning in vocational 
education: Challenges to vocational educators. Teaching and Teacher Education, 27, 694-702. doi: 10.1016/j.tate.2010.11.007

DeCavalho, R.J. (1991). The humanistic paradigm in education. The Humanistic Psychologist, 19(1), 88-104. doi: 10.1080/08873267.1991.9986754

De Groot, I. (2011). Why we are not democratic yet: The complexity of developing a democratic attitude. In W. Veugelers (Ed.), Education and humanism: Linking autonomy and humanity (pp. 79-94). Rotterdam, Netherlands: Sense Publishers.

Dennen, V.P. (2001). Cognitive apprenticeship in educational practice: Research on scaffolding, modeling, mentoring, and coaching as instructional strategies. In D.H. Jonassen (Ed.), Handbook of research for educational communications and technology (pp. 813-828). Bloomington, IN: The Association for Educational Communication and Technology.

Edmiston, B. (2014). Transforming teaching and learning with active and dramatic approaches: Engaging students across the curriculum. New York, NY: Routledge.

Elias, J.L., \& Merriam, S.B. (2005). Philosophical foundations of adult education (3rd ed.). Malabar, FL: Krieger.

Falk, B. (2009). Teaching the way children learn. New York, NY: Teachers College Press.

Flick, U. (2002). Qualitative Sozialforschung: Eine Einführung [Qualitative research in the social sciences: An introduction] (2nd ed.). Hamburg, Germany: Rowohlt.

Frydaki, E. (2011). Fostering humanity through interpretive dialogue in teacher communities. In W. Veugelers (Ed.), Education and humanism: Linking autonomy and humanity (pp. 163-179). Rotterdam, Netherlands: Sense Publishers.

Fürstenau, B. (2003). Exploration of an industrial enterprise as a method of boundarycrossing in vocational education. In T. Tuomi-Gröhn \& Y. Engeström (Eds.), Between school and work: New perspectives on transfer and boundary crossing (pp. 85-118). Kidlington, Oxford, United Kingdom: Elsevier Science.

Gitlin, A., \& Peck, M. (2005). Educational poetics: Inquiry, freedom, and innovative necessity. New York, NY: Peter Lang.

Gordon, H.R.D. (2014). The history and growth of career and technical education in America (4th ed.). Prospect Heights, IL: Waveland Press.

Gray, K.C., and Herr, E.L. (1998). Workforce education: The basics. Boston, MA: Allyn \& Bacon.

Greenleaf, W.T., \& Griffin, G.A. (1971). Schools for the 70s and beyond: A call to action. Washington, DC: National Education Association of the United States.

Hickox, M., \& Moore, R. (1995). Liberal-humanist education: The vocational challenge. Curriculum Studies, 3(1), 45-59. doi: 10.1080/0965975950030103

Hitt, W.D. (1973). Education as a human enterprise. Worthington, OH: Charles A. Jones.

Hopkins, R.L. (1994). Narrative schooling: Experiential learning and the transformation of American education. New York, NY: Teachers College Press.

Johnson, E.B. (2002). Contextual teaching and learning: What it is and why it's here to stay. Thousand Oaks, CA: Corwin Press.

Kincheloe, J.L. (1995). Toil and trouble: Good work, smart workers, and the integration 
of academic and technical education. New York, NY: Peter Lang.

Kincheloe, J.L. (1999). How do we tell the workers? The socioeconomic foundations of work and vocational education. Boulder, CO: Westview Press.

Kraft, A. (1975). The living classroom: Putting humanistic education into practice. New York, NY: Harper and Row.

Kvale, S., \& Brinkmann, S. (2009). InterViews: Learning the craft of qualitative research interviewing. Los Angeles, CA: Sage Publications.

Law, G.F. (1980). Supervision: A lost art. In A.A. Cross (Ed.), Vocational instruction (pp. 51-56). Arlington, VA: American Vocational Association.

Lee, V.S., Greene, D.B., Odom, J., Schechter, E., \& Slatta, R.W. (2004). What is inquiry-guided learning? In V.S. Lee (Ed.), Teaching and learning through inquiry: A guidebook for institutions and instructors (pp. 3-16). Sterling, VA: Stylus.

Lincoln, Y.S., \& Guba, E.G. (1985). Naturalistic inquiry. Thousand Oaks, CA: Sage.

Loftis, H.A. (1980). An exemplary model for change. In A.A. Cross (Ed.), Vocational instruction (pp. 25-36). Arlington, VA: American Vocational Association.

Merriam, S.B. (2009). Qualitative research: A guide to design and implementation (3rd ed.). San Francisco, CA: John Wiley and Sons.

Miller, M.D., \& Gregson, J.A. (1999). A philosophic view for seeing the past of vocational education and envisioning the future of workforce education: Pragmatism revisited. In A.J. Pautler, Jr. (Ed.), Workforce education: Issues for the new century (pp. 21-34). Ann Arbor, MI: Prakken.

Morse, J. M., \& Richards, L. (2002). Readme first for a user's guide to qualitative methods. Thousand Oaks, CA: Sage.

Nakata, K. (1972). Business administration and education. In C. Weinberg (Ed.), Humanistic foundations of education (pp. 227-254). Englewood Cliffs, NJ: PrenticeHall.

National Commission on Excellence in Education, The. (1983). A nation at risk: The full account. Cambridge, MA: USA Research.

Nemiroff, G.H. (1992). Reconstructing education: Toward a pedagogy of critical humanism. New York, NY: Bergin \& Garvey.

Newcomb, L.H. (1980). The humanistic teacher. In A.A. Cross (Ed.), Vocational instruction (pp. 17-24). Arlington, VA: American Vocational Association.

Patterson, C.H. (1973). Humanistic education. Englewood Cliffs, NJ: Prentice-Hall.

Patterson, C.H. (1987). What has happened to humanistic education? Michigan Journal of Counseling and Development, 18(1), 8-10.

Patton, M.Q. (2002). Qualitative research and evaluation methods (3rd ed). Thousand Oaks, CA: Sage.

Roberts, J.W. (2012). Beyond learning by doing: Theoretical currents in experiential education. New York, NY: Routledge.

Rogers, C.R., \& Freiberg, H.J. (1994). Freedom to learn (3rd ed.). New York, NY: Maxwell Macmillan International.

Rossman, G.B., \& Rallis, S.F. (2003). Learning in the field: An introduction to qualitative research. (2nd ed.). Thousand Oaks, CA: Sage.

Rubin, J., \& Rubin, I. (1995). Qualitative interviewing: The art of hearing data. Thou- 
sand Oaks, CA: Sage Publications.

Savin-Baden, M., \& Major, C.H. (2013). Qualitative research: The essential guide to theory and practice. Milton Park, Abingdon, United Kingdom: Routledge.

Scott, J.L., \& Sarkees-Wircenski, M. (2008). Overview of career and technical education (4th ed.). Homewood, IL: American Technical Publishers.

Scott, P. (1980). Individualizing vocational education. In A.A. Cross (Ed.), Vocational instruction (pp. 105-114). Arlington, VA: American Vocational Association.

Sears, S.J., \& Hersh, S.B. (1998). Contextual teaching and learning: An overview of the project. In K.R. Howe, S. Sears, R. Berns, J. DeStefano, \& S. Pritz (Eds.), Contextual teaching and learning: Preparing teachers to enhance student success in and beyond school (pp. 1-18). Columbus, OH: ERIC Clearinghouse on Adult, Career, and Vocational Education and Washington, DC: ERIC Clearinghouse on Teaching and Teacher Education.

Shapiro, S.B. (1986). Survey of basic instructional value in humanistic education. Journal of Humanistic Education and Development, 24 (4), 144-158.

Simpson, E.L. (1976). Human education: An interpretation. Cambridge, MA: Ballinger.

Spitze, H.T. (1980). Instructional materials and techniques. In A.A. Cross (Ed.), Vocational instruction (pp. 123-132). Arlington, VA: American Vocational Association.

Stephens, G.E. (2015). Uncertified and teaching: Industry professionals in career and technical education classrooms. International Journal for Research in Vocational Education and Training, 2(2), 119-135.

Veugelers, W. (2011a). Introduction: Linking autonomy and humanity. In W. Veugelers (Ed.), Education and humanism: Linking autonomy and humanity (pp. 1-7). Rotterdam, Netherlands: Sense Publishers.

Veugelers, W. (2011b). A humanist perspective on moral development and citizenship education. In W. Veugelers (Ed.), Education and humanism: Linking autonomy and humanity (pp. 9-34). Rotterdam, Netherlands: Sense Publishers.

Weimer, M. (2002). Learner-centered teaching: Five key changes to practice. San Francisco, CA: Jossey-Bass.

Weinberg, C., \& Reidford, P. (1972). Humanistic educational psychology. In C. Weinberg (Ed.), Humanistic foundations of education (pp. 101-132). Englewood Cliffs, NJ: Prentice-Hall.

Westheimer, J. (2011). Practicing democracy. In W. Veugelers (Ed.), Education and humanism: Linking autonomy and humanity (pp. 95-103). Rotterdam, Netherlands: Sense Publishers.

Willers, J.C. (1975). Humanistic education: Concepts, criteria, and criticism. Peabody Journal of Education, 53(1), 39-44. doi: 10.1080/01619567509538047

Winther, E., \& Achtenhagen, F. (2009). Measurement of vocational competencies: A contribution to an international large-scale assessment on vocational education and training. Empirical Research in Vocational Education and Training, 1, 85-108.

Winther, E., \& Klotz, K. (2013). Measurement of vocational competences: An analysis of the structure and reliability of current assessment practices in economic domains. Empirical Research in Vocational Education and Training, 5(2), 26 para. Retrieved from https://ervet-journal.springeropen.com/articles/10.1186 /1877-6345-5-2 
Woolley, N.N., \& Jarvis, Y. (2007). Situated cognition and cognitive apprenticeship: A model for teaching and learning critical skills in a technologically rich and authentic learning environment. Nurse Education Today, 27, 73-79. doi: 10.1016/j.nedt.2006.02.010

Zahorik, J.A., \& Brubaker, D.L. (1972). Toward more humanistic instruction. Dubuque, IA: W.C. Brown. 


\section{Bibliographical Notes}

Dr Peng Chen is Associate Professor in the School of Education Science at Jiangsu Normal University in Xuzhou, PR China. His research interests focus on curriculum and instruction in vocational education, philosophy of vocational education, and vocational preparation.

Dr Carsten Schmidtke is Assistant Professor of Human Resource and Workforce Education at the University of Arkansas in Fayetteville, Arkansas, USA. His research includes vocational education theory, international workforce education issues, and postsecondary workforce education. He is the editor of American Indian Workforce Education: Trends and Issues, a collection of articles on the current status of vocational education for American Indians. 